\title{
An investigation of the nexus between globalisation dimensions and income inequality
}

\author{
Zita Tamasauskiene, Skaidrè Žičkienè
}

\begin{abstract}
A B S T R A C T
Objective: The objective of the article is to explore the nexus between changes of various globalisation dimensions, defined by either policy (de jure) or outcomes (de facto), and the rise in income inequality in a panel of 27 EU countries during the period 1998-2017.

Research Design \& Methods: In order to tackle endogeneity issues, the effect is empirically tested applying the appropriate one-step system generalised method of moments (GMM) technique. Globalisation is measured by the de jure and de facto trade, financial, social, and political KOF globalisation indexes. Income inequality is measured by net Gini. To examine the sensitivity of our findings, we apply the decile ratio and quintile ratio as dependent variables.

Findings: We have found several significant results. First, de jure trade and de jure financial globalisation exert a big affirmative influence on income inequality and suggest that changes in trade and financial policy have increased inequality in the EU countries. Second, the results testify that de jure and de facto political globalisation influence income inequality in various ways and opposing directions. Finally, the effect of social globalisation on income inequality lacks statistical significance.

Implications \& Recommendations: De jure trade and financial globalisation measures which are based on tariffs, trade taxes, trade and investment regulations, etc. increase income inequality. Therefore, policymakers need to rethink their approach to trade and financial globalisation policy and ensure that the increasing benefits of globalisation and rising income would be distributed more equally between different groups of the population.

Contribution \& Value Added: Economic literature has focused on the effect of different single indicators of economic globalisation on income distribution and inequality, while the effect of various globalisation dimensions is almost nonexistent. Contrary to previous studies, we also distinguish between de jure and de facto indicators of various dimensions of globalisation and reveal that they have diverse impacts on income inequality.

\begin{tabular}{lll}
\hline Article type: & research article & \\
Keywords: & globalisation; dimensions of globalisation; income inequality; panel data; European Union \\
JEL codes: & D63, F60, D31, C23, O52 & \\
\hline \multicolumn{1}{c}{ Received: 2 June 2020} & Revised: 12 February 2021 & Accepted: 15 March 2021
\end{tabular}
\end{abstract}

\section{Suggested citation:}

Tamasauskiene, Z., \& Žičkienė, S. (2021). An investigation of the nexus between globalization dimensions and income inequality. Entrepreneurial Business and Economics Review, 9(2), 39-53. https://doi.org/10.15678/EBER.2021.090203

\section{INTRODUCTION}

Over recent decades, income and wealth inequality have changed in many countries of the world. High inequality in many economies is one of the biggest economic and social challenges for researchers and politicians. At the same time, however, globalisation has expanded in many countries of the world. In recent decades, the cross-border flows of goods, capital and people have increased dramatically, international trade has intensified and become more global, economies of different countries have become more dependent on the financial sector, capital has become more mobile, labour markets more flexible. An important issue these days is the influence of globalisation on growth, sustainable development, income, and wealth inequality. 
Actual evidence on the nexus between globalisation and inequality is surprisingly contradictory. Several studies have found a positive link and sustain the hypothesis that globalisation increases inequality (Jaumotte et al., 2013; Bergh \& Nilsson, 2010; Cabral et al., 2016; Gozgor \& Ranjan, 2015). The results of other investigations (Zhou et al., 2011; Faustino \& Vali, 2013) show a negative nexus between trade openness and income inequality. Other studies (Roine et al., 2009), by contrast, find that neither trade openness nor financial integration has a clear effect on inequality, or find (Babones \& Vonada, 2009) that inequality is not robustly related to trade globalisation.

In the studies mentioned above, the impact of globalisation on income equality was assessed using various single measures of economic globalisation: foreign direct investment (FDI), relative import and export prices, trade openness, tariff rates, capital account openness, etc. Yet, globalisation is not solely an economic process. Therefore, it is vital to consider the potential influence of political and social globalisation on income inequality. Furthermore, researchers do not distinguish between the effect of de jure and de facto indicators of globalisation on income inequality. If de jure indicators involve variables that incorporate institutions, resources, or policies empowering or alleviating real flows and activities, de facto indicators incorporate variables that express actual flows (Gygli et al., 2019, p. 2). Merging de jure and de facto globalisation indicators in one index may have probable distorting impacts in later applications (Martens et al., 2015, p. 5).

The goal of this article is to explore the nexus between changes of various globalisation dimensions, defined by either policy (de jure) or outcomes (de facto), and changes in income inequality. The research is conducted using panel data of EU 27 countries for the time from 1998 to 2017.

The contribution of the investigation is two-fold. First, we identify the influence of globalisation on disposable income inequality through several dimensions, the economic (trade and financial), the political and social, as well as two indicators, de facto and de jure for every dimension. The selection of measures has significant consequences for empirical analysis (Kose et al., 2009, p. 9).

To the best of our knowledge, Dreher and Gaston (2008) were the first to explore the effect of diverse dimensions of globalisation on household income inequality. Some researchers (Potrafke, 2013; Eppinger \& Potrafke, 2016) use the KOF globalisation index as an instrumental variable for trade openness. However, these empirical investigations neglect the issue of how de facto and de jure indicators of various globalisation dimensions impact income inequality. Second, most of the studies in this field apply static panel data models. We use the one-step system generalised method of moments (GMM) dynamic panel estimator which explicitly takes into consideration potential endogeneity problems.

The remaining part of the article is structured as follows: part two reviews the literature concerning the impact of globalisation on disposable income inequality and formulates the hypotheses we examine in this research. The data and indicators used in the regression model are described in part three. The next part develops the model and methodology. Finally, we present the results of empirical analysis and discussion. The article ends with conclusions.

\section{LITERATURE REVIEW}

Income inequality is a product of macro processes, structural conditions, and institutional constructs. In the scientific literature, there is no unanimous attitude on the factors affecting income differentiation and inequality. Researchers (Jaumotte et al., 2013; Kochan \& Riordan, 2016) distinguish the following main causes of changing income inequality: technological change, trade globalisation, and financial globalisation. Schmid and Stein (2013) emphasize that the key factors determining income inequality are: cyclical and structural changes in the labour market, raising capital income and declining efficiency of public income redistribution. According to Tridico and Pariboni (2018), financialisation of economies in conjunction with globalisation generated the main mechanism which led to increasing income inequality. Although there is a disagreement over the direction of the influence of various globalisation dimensions on income inequality, most of the researchers agree that globalisation is one of the main determinants of income inequality.

The traditional international trade theory predicts that an increase in trade openness changes relative wages and salaries of higher-skilled employees in developed countries and increases inequality 
in these countries. This theory relies on the Stolper-Samuelson theorem and anticipates that trade liberalisation will be good for the relatively plentiful factor. This factor will gain from international trade because liberalisation increases the price of it in real and nominal terms. Since developed countries are relatively abundant in physical and human capital, the theory anticipates that the liberalisation of trade will boost inequality in those countries.

But the Stolper-Samuelson theorem assumes full employment of workers and immobility of labour and capital. However, in recent years capital and labour mobility has increased. Trying to overcome shortcomings of the Stolper-Samuelson theorem during the past decades, new theories have been developed in the attempt to describe channels through which globalisation may affect income inequality. Dynamic industry theory (Melitz, 2003) takes into account the heterogeneity of firms in various branches of industries in leading and growing economies. According to this theory, firms producing products for export can hire more productive employees and pay them higher wages. This leads to increased wage inequality among sectors and higher income inequality.

Figini and Gorg (1999) proposed a hypothesis according to which multinational companies not only outsource activities using a large amount of low-qualified labour but also introduce new technologies in developing countries. The research results show that initially new technologies increase demand for qualified workers, which raises their relative wages, salaries and increases income inequality. However, in the second phase, wage inequality may decrease when previously low-skilled workers become more skilled because of the experience they gain using new technologies.

Many empirical studies have explored the relationship between globalisation and the distribution of income, but findings are highly mixed and inconclusive. Cabral et al. (2016) found that globalisation affects income concentration through the measure of financial integration which is based on portfolio equity and FDI stocks. Results suggest that globalisation impacts income concentration and inequality through FDI/equity flows channel. The study by Dreher and Gaston (2008) uses the KOF globalisation index in static and dynamic panel data models and shows that globalisation enhances inequality particularly in OECD countries.

However, the results of other researchers are in stark contrast and show that the influence of globalisation on income inequality is negative. Zhou et al. (2011), for instance, use two new indices of globalisation (the Kerney index and the principal components) and found a negative nexus between globalisation and income inequality. Jestl et al. (2018) investigate the effects of three dimensions of globalisation on wage inequality. Their results show that the effect of various globalisation dimensions is miscellaneous: migration and FDI increase wage inequality in the sample of 14 old EU countries, trade is the essential wage inequality cause in the new EU Member Countries.

It is necessary to mention that in empirical studies most commonly used indicators for globalisation are trade openness, relative import and export prices, and offshoring capital account liberalisation. Generally, it can be stated that investigation in this area is not yet conclusive and the results on the nexus between globalisation and income inequality are still mixed. The results differ depending on different models used to assess the nexus between globalisation and income inequality, estimation methods, explained and explanatory variables in regression analysis, data quality, and sample coverage.

The simplest international trade model predicts that increasing trade globalisation (through tariff reduction) worsens the distribution of income in developed countries. There are different ways how international trade may affect income inequality. Trade policy changes (taxes, customs tariffs, trade agreements) may increase employment opportunities but simultaneously may contribute to a lower wage share in national income, higher relative wages of skilled workers, wider wage differentiation. Stolper-Samuelson theorem also predicts trade liberalisation will increase inequality in developed countries. Globalisation may increase inequalities of relative wages among qualified and unqualified workers. From the above, we assume that:

H1: De facto globalisation of trade is linked to a rise in income inequality.

H2: De jure globalisation of trade is linked to a rise in income inequality.

The theory offers ambiguous predictions on the impact of financial globalisation on income inequality. Financial globalisation can allocate international capital more efficiently and stimulate inter- 
national risk sharing (Dabla-Norris et al., 2015, p. 20). FDI usually concentrates in technology-intensive higher-skilled sectors. This increases the demand for highly qualified workers and their wages. Feenstra and Hanson (1997) assert that FDI increases the demand for skilled workers and their wages in developed and developing economies. Some researchers argue that increased liberalisation of capital account may magnify the access of poor people to financial resources, but other scientists assert that it may disproportionately hurt the poor by increasing the probability of a financial crisis (IMF, 2007, p. 149). If financial flows are available to all people, they may decrease inequality by permitting human capital investments. But if financial resources are accessible only to those who have accumulated human capital, higher relative income and security deposit, this would likely increase income inequality. Due to the above-mentioned reasons we propose to verify the following research hypotheses:

H3: De facto financial globalisation is linked to a decrease in income inequality.

H4: De jure financial globalisation is linked to a rise in income inequality.

The theoretical forecasts concerning the nexus between political globalisation and income inequality are vague. By Dreher (2006), political globalisation sets minimum standards and therefore enhances equality within countries. Tsai (2007) reveals the affirmative effect of political globalisation on human welfare. The results of Yay et al. (2016) from fixed-effects estimations show that political globalisation measured by the KOF index has an affirmative impact on wage inequality. Bergh and Nilsson (2010) found that political globalisation does not increase inequality. According to Martens et al. (2015), there is a distinct difference between de jure and de facto indicators of globalisation. These indicators may vary considerably if a policy is rigorous on paper but helpless in practice (Kose et al., 2009). The effect of political globalisation is likely to differ depending on the indicators of political globalisation. From the above, it is hypothesised that:

H5: De facto political globalisation is linked to a rise in income inequality.

H6: De jure political globalisation is linked to a decrease in income inequality.

There are no formal theories that forecast any distinct influence of social globalisation on wealth and income inequality. Shahbaz et al. (2018) point out that social globalisation connects people by enhancing flows of information and cultural closeness. Dorn et al. $(2017$, p. 9) emphasize that social globalisation may influence the distribution of income and inequality by augmenting information exchange, promoting migration and economic transactions. The baseline results of Bergh and Nilsson (2010) show an affirmative nexus between social globalisation and income inequality. Relying on this, we propose the hypothesis:

H7: De facto social globalisation and de jure social globalisation are related to a rise in income inequality.

\section{RESEARCH METHODOLOGY}

To investigate empirically the relationship between changes of various globalisation dimensions, defined either by policy or outcomes, and income inequality we use an unbalanced panel data covering $27 \mathrm{EU}$ member states. Scientists use various income inequality measurement metrics. Income inequality may be measured using a variety of indicators: the Gini coefficient, decile ratios, quintile ratios, top income shares, bottom income shares, the Palma ratio, the Atkinson index, the Theil index, the Generalised entropy index. We follow researchers Agnello et al. (2012), Pérez-Moreno and Angulo-Guerrero (2016), Asteriou et al. (2014), Kunieda et al. (2014), Sánchez-López et al. (2019) who investigate the nexus among globalisation and income inequality and use the net Gini index for income inequality measurement. Moreover, Sánchez-López et al. (2019, p. 89) stress that "in order to make results comparable to those published in the literature" they use the Gini index after social transfers. Bergh and Nilsson (2010) do examine the influence of globalisation on inequality and also note that "preferred distributional measure and dependent variable is the net income Gini coefficient". Net income inequality is the distribution that matters for peoples' consumption possibilities (Brady \& Sosnaud, 2009). 
If income distribution is completely egalitarian, the Gini index is 0 . If all incomes are accumulated by one person, the Gini index is 1.

Following the study by Voigt et al. (2015), in which they separate de facto and de jure components of institutions, we use de facto and de jure indicators of various globalisation dimensions. For measures of economic (trade and financial), political, and social globalisation, defined either by policy (de jure) or outcomes (de facto), we employ the KOF indexes, presented in the database of the Swiss Federal Institute of Technology. Table 1 provides definitions of various globalisation dimensions. The KOF Index changes from 0 to 100, bigger index values show expanding globalisation and lower values explain otherwise.

Table 1. Definitions of variables and their sources

\begin{tabular}{|c|c|c|c|}
\hline Indicator name & $\begin{array}{c}\text { Short name } \\
\text { of the vari- } \\
\text { able }\end{array}$ & Description & Data source \\
\hline \multicolumn{4}{|c|}{ Inequality variables } \\
\hline $\begin{array}{l}\text { Post-tax/transfer net } \\
\text { Gini }\end{array}$ & GINI & $\begin{array}{l}\text { Net income Gini coefficient is calculated by the } \\
\text { formula }\end{array}$ & EUROSTAT-SILC \\
\hline $\begin{array}{l}\text { Interquintile ratio of } \\
\text { disposable income }\end{array}$ & Q5/Q1 & $\begin{array}{l}\text { Top quintile share of income divided by bottom } \\
\text { quintile share of income (Q5/Q1) }\end{array}$ & $\begin{array}{l}\text { World Income Ine- } \\
\text { quality Database }\end{array}$ \\
\hline $\begin{array}{l}\text { Interdecile ratio of dis- } \\
\text { posable income }\end{array}$ & $D 10 / D 1$ & $\begin{array}{l}\text { Top decile share of income divided by bottom dec- } \\
\text { ile share of income (D10/D1) }\end{array}$ & $\begin{array}{l}\text { World Income Ine- } \\
\text { quality Database }\end{array}$ \\
\hline \multicolumn{4}{|c|}{ KOF Globalisation Indexes and variables included in its calculation } \\
\hline $\begin{array}{l}\text { De facto trade globali- } \\
\text { sation }\end{array}$ & KOFTrF & $\begin{array}{l}\text { Trade in services, Trade in goods, Trade partner di- } \\
\text { versity }\end{array}$ & \multirow{8}{*}{$\begin{array}{l}\text { KOF Swiss Eco- } \\
\text { nomic Institute }\end{array}$} \\
\hline $\begin{array}{l}\text { De jure trade globalisa- } \\
\text { tion }\end{array}$ & KOFTrJ & $\begin{array}{l}\text { Trade regulations, Trade agreements, Tariffs, } \\
\text { Trade taxes }\end{array}$ & \\
\hline $\begin{array}{l}\text { De facto financial glob- } \\
\text { alisation }\end{array}$ & KOFFiF & $\begin{array}{l}\text { Portfolio investment, FDI, International reserves, } \\
\text { International income payments, International debt }\end{array}$ & \\
\hline $\begin{array}{l}\text { De jure financial glob- } \\
\text { alisation }\end{array}$ & KOFFiJ & $\begin{array}{l}\text { Capital account openness, Investment restrictions, } \\
\text { International Investment agreements }\end{array}$ & \\
\hline $\begin{array}{l}\text { De facto political glob- } \\
\text { alisation }\end{array}$ & KOFPOF & $\begin{array}{l}\text { International NGOs, Embassies, UN peace keeping } \\
\text { missions }\end{array}$ & \\
\hline $\begin{array}{l}\text { De jure political global- } \\
\text { isation }\end{array}$ & KOFPOJ & $\begin{array}{l}\text { International treaties, International organisations, } \\
\text { Treaty partner diversity }\end{array}$ & \\
\hline $\begin{array}{l}\text { De facto social (infor- } \\
\text { mational) globalisa- } \\
\text { tion }\end{array}$ & KOFSOF & $\begin{array}{l}\text { International patents, Used internet bandwidth, } \\
\text { High technology exports }\end{array}$ & \\
\hline $\begin{array}{l}\text { De jure social (infor- } \\
\text { mational) globalisation }\end{array}$ & KOFSOJ & Internet access, Television access, Press freedom & \\
\hline \multicolumn{4}{|c|}{ Control variables } \\
\hline $\begin{array}{l}\text { Schooling (mean } \\
\text { years) }\end{array}$ & School & $\begin{array}{l}\text { Average number of years of education acquired by } \\
\text { people aged } 25 \text { and older }\end{array}$ & $\begin{array}{l}\text { Human Develop- } \\
\text { ment Data }\end{array}$ \\
\hline $\begin{array}{l}\text { Population share with } \\
\text { tertiary education }\end{array}$ & Tertiary & $\begin{array}{l}\text { Population share with finished tertiary education } \\
\text { (age 15-64, levels 5-8) }\end{array}$ & Eurostat \\
\hline $\begin{array}{l}\text { Expenditure on social } \\
\text { protection }\end{array}$ & SocProt & Expenditure on social protection $\%$ of GDP & Eurostat \\
\hline GDP per capita & GDPperC & GDP per capita units in national currency & Eurostat \\
\hline Dependency & Depend & $\begin{array}{l}\text { The proportion of the population over } 64 \text { and un- } \\
\text { der } 15\end{array}$ & $\begin{array}{l}\text { Calculated by au- } \\
\text { thors using Euro- } \\
\text { stat data }\end{array}$ \\
\hline $\begin{array}{l}\text { Business research and } \\
\text { development }\end{array}$ & $R \& D b u s$ & Business expenditure on R\&D as \% of total GDP & Eurostat \\
\hline $\begin{array}{l}\text { Government research } \\
\text { and development }\end{array}$ & $R \& D g o v$ & Government expenditure on R\&D as \% of total GDP & Eurostat \\
\hline
\end{tabular}

Source: own study. 
De facto trade globalisation index (KOFTrF) is calculated using data on trade in services, trade in goods and trade partner diversity. De jure trade globalisation index (KOFTrJ) combines measures of trade regulations, trade agreements, tariffs, and trade taxes. De facto financial globalisation index (KOFFiF) combines measures of portfolio investment, FDI, international reserves, international income payments, and International debt. De jure financial globalisation index (KOFFiJ) is calculated using data on capital account openness, investment restrictions, international investment agreements. The de facto measure of political globalisation (KOFPOF) captures the effect of international NGOs, embassies, and UN peace keeping missions. To measure de jure KOF political globalisation (KOFPOJ), the following variables are used: international treaties, international organisations, and treaty partner diversity. In the research, we measure social globalisation using de facto and de jure KOF informational globalisation indexes.

In order to increase the explanatory power of various aspects of globalisation on income inequality in all model specifications, we incorporate control variables: mean years of schooling (School), tertiary education (Tertiary), expenditure on social protection (SocProt), GDP per capita (GDPperC), the dependency ratio (Depend) as well as business enterprise R\&D expenditure (R\&Dbus) and government sector R\&D expenditure ( $R \& D g o v)$.

To check the influence of accumulated human capital in the different populations on income inequality, we include the variable of population share with finished tertiary education (Tertiary). In principle, the effect of higher education on income inequality is uncertain. It is expected that a greater access to higher education reduces income inequality as more employees can work in highly skilled jobs.

Therefore, education may have a notable contribution to reducing income inequality. However, it can also raise wage and income inequality when the wage premium of people with tertiary education increases. Following Cassette et al. (2012) to capture human capital development on income inequality we also include average years of schooling.

Income inequality depends on government social and labour policies. Governments mitigate income and wealth inequality via different public policy measures: progressive tax system and social assistance programmes. Theoretically, there is a basis to foresee that countries in which welfare systems are larger and expenditure on social protection bigger have lesser inequality because transfers of the public sector are considered to have a countervailing effect (see e.g. Åberg, 1989). We expect a negative relationship between SocProt and income inequality.

Research results show that the GDPperC level is related to income distribution and inequality (see Berg et al., 2012). Further, demographic factors and differences in income between workers and retired persons might also affect inequality. Following Bergh and Nilsson (2010) we include Depend ratio. This measure shows the proportion of the population whose age is lower than 15 and higher than 64 years and demonstrates the modification of people's age distribution. We expect that a bigger ratio of dependency will be linked to greater inequality.

Technological change is also considered as a potential factor in causing rising income inequality. For example, Dorn et al. (2017) assert that ignoring technological change in empirical assessment may cause an omitted variable bias. We control the technological progress by using R\&Dbus and R\&Dgov. Table 2 presents summary statistics of dependent and independent variables.

We use a panel data regression in this research. The advantage of applying the panel model is that it uses cross-sectional and time-series variations in the data. The following GMM model is used, and countries are indicated by $i$ and 4-year-averages by $\tau$ :

$$
Y_{i, \tau}=\partial Y_{i, \tau-1}+\beta_{1} G F_{i, \tau}+\beta_{2} G J_{i, \tau}+\gamma^{\prime} X_{i, \tau}+\vartheta_{\tau}+\varepsilon_{i, \tau}
$$

Where: $Y_{i, \tau}$ is the dependent variable, income inequality measure; $Y_{i, \tau-1}$ is a one period lag of income inequality measure; $G F_{i, \tau}$ denotes de facto measures of various globalisation dimensions (KOF indexes of de facto trade, financial, political and social globalisation in various model specifications), $G J_{i, \tau}$ denotes de jure indicators of various globalisation dimensions (KOF indexes of de jure trade, financial, political and social globalisation in various model specifications). We will test the hypothesis whether $\beta_{1}$ and $\beta_{2}$ are positive/negative and significantly different from zero. $X_{i, \tau}$ is a vector of control variables including School, Tertiary, SocProt, GDPperC, Depend, R\&Dbus, R\&Dgov. These variables are also used in the model as a test of sensitivity. Finally, $\vartheta_{\tau}$ is fixed period effects; and $\varepsilon_{i, \tau}$ represents the 
error term. To reduce skewness and heteroscedasticity of data and to facilitate the interpretation of coefficients we use dependent and independent variables in natural logarithms and transform a model into the linear one. We employ one-step system GMM procedures, using the GRETL programme.

Table 2. Descriptive statistics of dependent and independent variables

\begin{tabular}{|l|r|r|r|r|r|}
\hline \multirow{2}{*}{ Short name of the variable } & \multicolumn{5}{c|}{ 27 EU countries } \\
\cline { 2 - 6 } & \multicolumn{1}{|c|}{ Min } & \multicolumn{1}{c|}{ Average } & \multicolumn{1}{c|}{ Max } & \multicolumn{1}{c|}{ SD } & Skewness \\
\hline GINI & 21 & 29.676 & 38.9 & 4.012 & 0.159 \\
\hline Q5/Q1 & 3.000 & 4.878 & 13.185 & 1.236 & 0.869 \\
\hline D10/D1 & 4.707 & 8.177 & 18.067 & 2.741 & 1.235 \\
\hline KOFTrF & 30.016 & 63.883 & 89.462 & 15.312 & -0.307 \\
\hline KOFTrJ & 46.449 & 86.744 & 97.752 & 9.492 & -2.14 \\
\hline KOFFiF & 30.734 & 78.025 & 97.726 & 14.528 & -0.927 \\
\hline KOFFiJ & 28.406 & 76.177 & 93.165 & 12.028 & -1.233 \\
\hline KOFPoF & 35.046 & 82.894 & 98.026 & 15.032 & -1.654 \\
\hline KOFPoJ & 53.853 & 89.631 & 100 & 10.772 & -1.372 \\
\hline KOFSOF & 46.562 & 75.88 & 98.326 & 9.342 & -0.312 \\
\hline KOFSOJ & 54.417 & 87.595 & 98.647 & 7.065 & -1.414 \\
\hline School & 6.7 & 11.055 & 14.1 & 1.396 & -0.561 \\
\hline Tertiary & 6.9 & 21.708 & 40.4 & 7.911 & 0.040 \\
\hline SocProt & 7.9 & 16.036 & 25.6 & 4.101 & 0.293 \\
\hline GDPperC & 1,400 & $20,655.7$ & 61,200 & 12,478 & 0.422 \\
\hline Depend & 35.778 & 43.873 & 54.095 & 3.971 & 0.138 \\
\hline RD\&bus & 0.01 & 0.847 & 3.03 & 0.687 & 0.886 \\
\hline RD\&gov & 0.01 & 0.193 & 0.42 & 0.091 & 0.408 \\
\hline SOurce Own & & & & & \\
\hline
\end{tabular}

Source: own study.

We use the GMM model because the relationship between our explanatory variables and income inequality may be dynamic: past income inequality may also affect current year inequality. We measure various dimensions of globalisation, using the KOF indexes. However, the main drawback of empirical research that uses the KOF indices is the endogeneity problem when there is reverse causation (Potrafke, 2015). Gradstein (2007) indicates that politicians reacting to changes in income inequality may implement policies which favour globalisation.

Moreover, when independent variables are not strictly exogenous, traditional OLS, FE, or RE panel data model estimators may be inconsistent and biased. The GMM model widens the FE estimator and involves the lagged dependent variable values as instruments to control for dynamic endogeneity (UIlah et al., 2018, p. 28). If endogeneity bias exists, researchers may obtain incorrect estimators (Ketokivi \& McIntosh, 2017). To tackle endogeneity problems in our data, we use the GMM estimator. The GMM model yields consistent results when there are various endogeneity sources, exactly "unobserved heterogeneity, simultaneity and dynamic endogeneity" (Wintoki et al., 2012, p. 588).

Following related studies, such as De Haan and Sturm (2017), Bergh and Nilsson (2010), we estimate the model, using non-overlapping five-year averages of variables for a few causes. First, dynamic onestep system GMM estimators require larger cross-sectional and fewer time points, as they are suitable for panels with short time dimensions $(T)$ in order to evade the proliferation of instruments when applying GMM. Second, annual data on income distribution and inequality are noisy. Third, Khadraoui and Smida (2012) emphasize that averaging data over a period also solves missing data problems and becomes popular in dynamic models. Finally, averages decrease the probability that outliers, measurement errors, and changes in the business cycle impact the findings (Dorn et al., 2017).

We calculate averages of 4-year accordingly: averaged annual 1998-2001 data were used as the observation for 2001; similarly, a 4-year averaged annual 2002-2005 data were taken as the value for 2005 and so on. Such calculations give us five time periods. The robustness of the link between various dimensions of globalisation and income inequality are examined using various dependent variables: quintile ratio and decile ratio. 
The one-step system GMM estimator provides consistent and efficient estimates if the instruments are valid and if there is no second-order autocorrelation. Before interpreting the results, we perform the Sargan test to determine the validity of the model, and if the employed instruments are exactly specified. In the realized models all instruments are valid and there is no endogeneity problem because the $p$-value of the Sargan overidentification test is higher than 0.05. The number of instruments must be similar to the number of the countries analysed. To check for second-order autocorrelation of errors, we also perform the Arellano-Bond test because the dependent variable Gini coefficient is lagged. There is no second-order autocorrelation of errors if the $p$-value is higher than 0.05 .

\section{RESULTS AND DISCUSSION}

In this part we submit the findings from panel regressions using one-step system GMM estimators. In contrast to the previous studies, we distinguish between the influence of de facto and de jure indicators of various globalisation dimensions on income inequality. Following Bergh and Nilsson (2010) and trying to avoid problems caused by multicollinearity, we include different dimensions of globalisation in different model specifications.

Table 3 shows the outcome of four GMM model specifications which differ solely by the included dimensions of globalisation. The estimates of the one-step system GMM regression show that de facto and de jure indicators of trade globalisation effects differently income inequality in $27 \mathrm{EU}$ countries.

The results of regression analysis show negative but statistically insignificant relationship between de facto trade globalisation (KOFTrF) and income inequality, which rejects hypothesis 1 . Our estimates also reveal the existence of the affirmative effect of de jure trade globalisation (KOFTrJ) on inequality and confirm hypothesis 2 . An Increase in KOFTrJ by $1 \%$ increases inequality by $0.4 \%$ (see specification 1 in Table 3). De jure measures of globalisation aim at capturing conditions that influence international transactions. Since large companies dominate in global markets, they affect trade policy by increasing liberalisation of restrictions and most frequently capture gains from international trade at the expense of small enterprises. Small enterprises cannot benefit from international trade because they are underrepresented in trade policy decision-making. The dominance of large firms in global markets has implications for how trade policy affects inequality. Our research results are in line with Bergh and Nilsson's (2010) findings that policy reforms favouring trade openness have raised inequality of income. Gourdon et al. (2008) also found that trade openness, measured by changes in tariffs, has a meaningful affirmative impact on inequality.

Regression results reject hypothesis 3, which states that de facto financial globalisation (KOFFiF) is linked to a decrease in income inequality. The country's openness to investment and international financial flows is measured by de jure financial globalisation index (KOFFiJ) (Gygli et al., 2019). Results of estimates reveal that there is an affirmative link between de jure financial globalisation and income inequality, thus supporting hypothesis 4 . A rise in de jure KOF globalisation index by $1 \%$ increases inequality by $0.2 \%$. Our results are in line with previous investigations which show that financial globalisation was the main driver of inequality (Asteriou et al., 2014). The research results of Lang and Tavares (2018, p. 24) show an affirmative and statistically significant impact of economic globalisation on net incomes Gini.

The results of regression analysis show an affirmative nexus between de facto political globalisation (KOFPOF) and inequality and confirm hypothesis 5 . An increase in KOFPoF index by $1 \%$ increases inequality by $0.11 \%$. As regards the impact of political globalisation on income inequality, the research results are in line with Lee et al. (2020), but they do not distinguish between the impact of different measures of political globalisation. Controversial results have also been found in the literature. Estimates show that de jure political globalisation (KOFPOJ), which indicates the ability to take part in the global political collaboration, has a negative and statistically significant effect on income inequality. The coefficient indicates that a $1 \%$ increase in the KOFPOJ index reduces inequality by $0.15 \%$. These results are not surprising due to the sophisticated link amongst the de jure political globalisation and income inequality; thus, they confirm hypothesis 6 which states that KOFPoj is linked to a decrease in 
income inequality. Estimates in Table 3 allow to reject hypothesis 7, which states that policy and outcomes of social globalisation are related to a rise in income inequality. It bears to emphasize that the effect of KOFSoF and KOFSoJ on income inequality is not statistically significant.

Table 3. Income inequality and diverse globalisation dimensions

\begin{tabular}{|c|c|c|c|c|}
\hline Variables & (1) & (2) & (3) & (4) \\
\hline Lagged GINI & $\begin{array}{c}0.591 * * * \\
(0.186)\end{array}$ & $\begin{array}{c}0.709 * * * \\
(0.176)\end{array}$ & $\begin{array}{c}0.566^{* * *} \\
(0.166)\end{array}$ & $\begin{array}{c}0.620^{* * *} \\
(0.138)\end{array}$ \\
\hline const & $\begin{array}{l}-0.888 \\
(0.659)\end{array}$ & $\begin{array}{l}-0.482 \\
(0.570)\end{array}$ & $\begin{array}{l}-0.052 \\
(0.464)\end{array}$ & $\begin{array}{c}0.130 \\
(0.919)\end{array}$ \\
\hline KOFTrF & $\begin{array}{l}-0.100 \\
(0.061)\end{array}$ & & & \\
\hline KOFTrJ & $\begin{array}{c}0.395 * * * \\
(0.114)\end{array}$ & & & \\
\hline KOFFiF & & $\begin{array}{l}-0.115 \\
(0.083)\end{array}$ & & \\
\hline KOFFiJ & & $\begin{array}{c}0.199 * * \\
(0.095)\end{array}$ & & \\
\hline KOFPoF & & & $\begin{array}{c}0.112^{* *} \\
(0.048)\end{array}$ & \\
\hline KOFPOJ & & & $\begin{array}{c}-0.148^{* *} \\
(0.071)\end{array}$ & \\
\hline KOFSOF & & & & $\begin{array}{l}-0.079 \\
(0.100)\end{array}$ \\
\hline KOFSOJ & & & & $\begin{array}{c}0.017 \\
(0.161)\end{array}$ \\
\hline School & $\begin{array}{c}0.073 \\
(0.061)\end{array}$ & $\begin{array}{l}-0.012 \\
(0.050)\end{array}$ & $\begin{array}{c}0.039 \\
(0.062)\end{array}$ & $\begin{array}{c}0.030 \\
(0.068)\end{array}$ \\
\hline Tertiary & $\begin{array}{c}0.011 \\
(0.024)\end{array}$ & $\begin{array}{c}0.007 \\
(0.027)\end{array}$ & $\begin{array}{l}-0.004 \\
(0.031)\end{array}$ & $\begin{array}{l}-0.008 \\
(0.024)\end{array}$ \\
\hline SocProt & $\begin{array}{l}-0.063 \\
(0.047)\end{array}$ & $\begin{array}{l}-0.016 \\
(0.045)\end{array}$ & $\begin{array}{l}-0.056 \\
(0.049)\end{array}$ & $\begin{array}{l}-0.064 \\
(0.047)\end{array}$ \\
\hline GDPperC & $\begin{array}{c}-0.049 * * \\
(0.016)\end{array}$ & $\begin{array}{l}-0.010 \\
(0.019)\end{array}$ & $\begin{array}{l}-0.007 \\
(0.014)\end{array}$ & $\begin{array}{l}-0.017 \\
(0.015)\end{array}$ \\
\hline Depend & $\begin{array}{l}0.352^{*} \\
(0.181)\end{array}$ & $\begin{array}{l}0.335^{*} \\
(0.202)\end{array}$ & $\begin{array}{c}0.415^{* *} \\
(0.172)\end{array}$ & $\begin{array}{c}0.522^{* * *} \\
(0.177)\end{array}$ \\
\hline RD\&bus & $\begin{array}{c}-0.027^{* *} \\
(0.013)\end{array}$ & $\begin{array}{c}-0.035^{* *} \\
(0.017)\end{array}$ & $\begin{array}{c}-0.031^{*} \\
(0.017)\end{array}$ & $\begin{array}{c}-0.042^{* *} \\
(0.019)\end{array}$ \\
\hline$R D \& g o v$ & $\begin{array}{l}-0.018 \\
(0.017)\end{array}$ & $\begin{array}{l}-5.248 \\
(0.016)\end{array}$ & $\begin{array}{l}-0.003 \\
(0.011)\end{array}$ & $\begin{array}{l}-0.011 \\
(0.016)\end{array}$ \\
\hline No of instruments & 22 & 22 & 22 & 22 \\
\hline $\operatorname{AR}(2)$ test $p$-value & $(0.445)$ & $(0.314)$ & $(0.288)$ & $(0.389)$ \\
\hline Sargan test $p$-value & $(0.620)$ & $(0.423)$ & $(0.708)$ & $(0.756)$ \\
\hline
\end{tabular}

Note: Standard errors are reported in parentheses. All regressions include time dummies. ${ }^{* * *},{ }^{* *}$ and ${ }^{*}$ show respectively the significance at the $1 \%, 5 \%$ and $10 \%$ confidence levels.

Source: own study.

The lagged net Gini income index is statistically significant in each model specification. The estimation results support the view that a higher proportion of retired individuals increases inequality. Finally, the $R \& D b u s$ coefficient indicates that a $1 \%$ increase in business expenditures reduces inequality by $0.03-0.4 \%$.

At the bottom of Tables 3 and 4 in conjunction with the regression coefficients we present the results of the required tests for checking the validity of the model. In all model specifications, the Sargan test $p$-value is bigger than 0.05 . This shows that the employed instruments are correctly specified and there are no endogeneity problems. There is no second-order autocorrelation of errors in all model specifications, moment conditions are valid the $p$-value ranges from 0.29 to 0.45 (Table 3 ) and is higher than 0.05 . The number of instruments (22) is not greater than the number of the countries (27). 
To get additional insight into the impact of various dimensions of globalisation on income inequality and then to verify the robustness of main findings we perform sensitivity checks by changing the measure of the dependent variable. Gini is the most frequently used indicator of inequality, but one limitation of the GINI is that it is more sensitive to changes around the mean (Dabla-Norris et al., 2015). Therefore, we additionally test the sensitivity of the results by using other inequality measures. We use decile ratios (D10/D1) and quintile ratios (Q5/Q1) as alternative measures of income inequality. These indicators are calculated using the World Income Inequality data.

Table 4. Sensitivity test: alternative measures of income inequality

\begin{tabular}{|c|c|c|c|c|c|c|c|c|}
\hline \multirow{2}{*}{ Variables } & \multicolumn{4}{|c|}{ Dependent variable - D10/D1 } & \multicolumn{4}{|c|}{ Dependent variable - Q5/Q1 } \\
\hline & (1) & (2) & (3) & (4) & (5) & (6) & (7) & (8) \\
\hline $\begin{array}{l}\text { Lagged depend- } \\
\text { ent variable }\end{array}$ & $\begin{array}{c}0.406^{* *} \\
(0.186)\end{array}$ & $\begin{array}{c}0.448 * * * \\
(0.163)\end{array}$ & $\begin{array}{c}0.45546^{* *} \\
(0.211)\end{array}$ & $\begin{array}{c}0.396^{* *} \\
(0.199)\end{array}$ & $\begin{array}{c}0.568^{* * *} \\
(0.142)\end{array}$ & $\begin{array}{c}0.594 * * * \\
(0.127)\end{array}$ & $\begin{array}{c}0.621 * * * \\
(0.150)\end{array}$ & $\begin{array}{c}0.573^{* * *} \\
(0.152)\end{array}$ \\
\hline const & $\begin{array}{l}-2.389 \\
(1.640)\end{array}$ & $\begin{array}{l}-0.849 \\
(1.794)\end{array}$ & \begin{tabular}{|l|}
-2.790 \\
$(2.009)$
\end{tabular} & $\begin{array}{l}-0.147 \\
(3.266)\end{array}$ & $\begin{array}{l}-0.789 \\
(1.251)\end{array}$ & $\begin{array}{c}-0.4 \\
(1.052)\end{array}$ & $\begin{array}{l}-1.056 \\
(0.956)\end{array}$ & $\begin{array}{l}-0.014 \\
(2.123)\end{array}$ \\
\hline KOFTrF & $\begin{array}{c}-0.299^{* *} \\
(0.088)\end{array}$ & & & & $\begin{array}{c}-0.168^{* * *} \\
(0.051)\end{array}$ & & & \\
\hline KOFTrJ & $\begin{array}{c}0.406 \\
(0.438)\end{array}$ & & & & $\begin{array}{c}0.142 \\
(0.303)\end{array}$ & & & \\
\hline KOFFiF & & $\begin{array}{l}-0.460 \\
(0.224) \\
\end{array}$ & & & & $\begin{array}{l}-0.171 \\
(0.142) \\
\end{array}$ & & \\
\hline KOFFiJ & & $\begin{array}{c}0.07 \\
(0.226) \\
\end{array}$ & & & & $\begin{array}{l}-0.023 \\
(0.134) \\
\end{array}$ & & \\
\hline KOFPoF & & & $\begin{array}{c}0.25 \\
(0.177) \\
\end{array}$ & & & & $\begin{array}{c}0.089 \\
(0.081)\end{array}$ & \\
\hline KOFPoJ & & & $\begin{array}{l}-0.217 \\
(0.217)\end{array}$ & & & & $\begin{array}{l}-0.153 \\
(0.113)\end{array}$ & \\
\hline KOFSOF & & & & $\begin{array}{l}-0.063 \\
(0.25)\end{array}$ & & & & $\begin{array}{l}-0.065 \\
(0.159)\end{array}$ \\
\hline KOFSOJ & & & & $\begin{array}{l}-0.494 \\
(0.501)\end{array}$ & & & & $\begin{array}{c}-0.23 \\
(0.337)\end{array}$ \\
\hline School & $\begin{array}{l}-0.019 \\
(0.224)\end{array}$ & $\begin{array}{l}-0.297 \\
(0.251)\end{array}$ & $\begin{array}{l}-0.164 \\
(0.281)\end{array}$ & $\begin{array}{l}-0.255 \\
(0.298)\end{array}$ & $\begin{array}{l}-0.019 \\
(0.135)\end{array}$ & $\begin{array}{l}-0.161 \\
(0.162)\end{array}$ & $\begin{array}{l}-0.113 \\
(0.159)\end{array}$ & $\begin{array}{l}-0.135 \\
(0.183)\end{array}$ \\
\hline Tertiary & $\begin{array}{c}0.017 \\
(0.076)\end{array}$ & $\begin{array}{c}0.031 \\
(0.083)\end{array}$ & $\begin{array}{l}-0.027 \\
(0.078)\end{array}$ & $\begin{array}{c}0.033 \\
(0.106)\end{array}$ & $\begin{array}{c}0.015 \\
(0.044)\end{array}$ & $\begin{array}{c}0.015 \\
(0.051)\end{array}$ & $\begin{array}{l}-0.017 \\
(0.044)\end{array}$ & $\begin{array}{c}0.014 \\
(0.064)\end{array}$ \\
\hline SocProt & $\begin{array}{c}-0.267^{* *} \\
(0.115) \\
\end{array}$ & $\begin{array}{c}-0.211^{* *} \\
(0.097) \\
\end{array}$ & $\begin{array}{l}-0.203^{*} \\
(0.119) \\
\end{array}$ & $\begin{array}{l}-0.201^{*} \\
(0.112) \\
\end{array}$ & $\begin{array}{c}-0.198^{* *} \\
(0.081) \\
\end{array}$ & $\begin{array}{c}-0.167^{* *} \\
(0.067) \\
\end{array}$ & $\begin{array}{l}-0.145^{*} \\
(0.078) \\
\end{array}$ & $\begin{array}{c}-0.160 * * \\
(0.074)\end{array}$ \\
\hline GDPperC & $\begin{array}{l}-0.089 \\
(0.057)\end{array}$ & $\begin{array}{c}0.015 \\
(0.049)\end{array}$ & $\begin{array}{l}-0.052 \\
(0.069)\end{array}$ & $\begin{array}{l}-0.031 \\
(0.051)\end{array}$ & $\begin{array}{l}-0.041 \\
(0.027)\end{array}$ & $\begin{array}{c}0.011 \\
(0.029)\end{array}$ & $\begin{array}{l}-0.012 \\
(0.034)\end{array}$ & $\begin{array}{l}-0.006 \\
(0.030)\end{array}$ \\
\hline Depend & $\begin{array}{c}1.193^{* * *} \\
(0.436)\end{array}$ & $\begin{array}{c}1.241^{* * *} \\
(0.428)\end{array}$ & $\begin{array}{l}1.396^{* *} \\
(0.603)\end{array}$ & $\begin{array}{c}1.387^{* * *} \\
(0.522)\end{array}$ & $\begin{array}{c}0.637^{* * *} \\
(0.227)\end{array}$ & \begin{tabular}{|c|}
$0.676^{* * *}$ \\
$(0.215)$ \\
\end{tabular} & $\begin{array}{c}0.732 * * * \\
(0.279) \\
\end{array}$ & $\begin{array}{c}0.729 * * * \\
(0.252) \\
\end{array}$ \\
\hline$R \& D b u s$ & $\begin{array}{l}-0.050 \\
(0.037)\end{array}$ & $\begin{array}{c}-0.066^{*} \\
(0.035)\end{array}$ & $\begin{array}{l}-0.089^{*} \\
(0.047)\end{array}$ & $\begin{array}{c}-0.083^{*} \\
(0.048)\end{array}$ & $\begin{array}{l}-0.022 \\
(0.024)\end{array}$ & $\begin{array}{l}-0.032 \\
(0.023)\end{array}$ & $\begin{array}{l}-0.041 \\
(0.028)\end{array}$ & $\begin{array}{l}-0.037 \\
(0.031)\end{array}$ \\
\hline$R \& D g o v$ & $\begin{array}{l}-0.051 \\
(0.050)\end{array}$ & $\begin{array}{c}-0.034 \\
(0.05)\end{array}$ & $\begin{array}{l}-0.027 \\
(0.056)\end{array}$ & $\begin{array}{l}-0.017 \\
(0.049)\end{array}$ & $\begin{array}{l}-0.027 \\
(0.025)\end{array}$ & $\begin{array}{l}-0.012 \\
(0.027)\end{array}$ & $\begin{array}{l}-0.002 \\
(0.028)\end{array}$ & $\begin{array}{l}-0.007 \\
(0.024)\end{array}$ \\
\hline $\begin{array}{l}\text { No of } \\
\text { instruments }\end{array}$ & 22 & 22 & 22 & 22 & 22 & 22 & 22 & 22 \\
\hline $\begin{array}{l}A R(2) \text { test } \\
p \text {-value }\end{array}$ & $(0.949)$ & $(0.624)$ & $(0.54)$ & $(0.5893)$ & $(0.621)$ & $(0.361)$ & $(0.340)$ & $(0.334)$ \\
\hline $\begin{array}{l}\text { Sargan test } \\
\text { p-value }\end{array}$ & $(0.758)$ & $(0.653)$ & $(0.524)$ & $(0.692)$ & $(0.594)$ & $(0.587)$ & $(0.471)$ & $(0.591)$ \\
\hline
\end{tabular}

Note: Standard errors are reported in parentheses. Regressions incorporate time dummies. ${ }^{* * *}, * *$ and $*$ show accordingly the significance at the $1 \%, 5 \%$ and $10 \%$ confidence levels.

Source: own study. 
The estimates with the decile ratio (D10/D1) and quintile ratio (Q5/Q1) as dependent variables are displayed in Table 4. De jure trade globalisation defined by policies (KOFTrJ), has a diverse influence on income inequality when comparing with de facto trade globalisation (KOFTrF) defined by outcomes. However, once we measure inequality by decile ratio (D10/D1) or quintile ratio (Q5/Q1), de jure trade globalisation (KOFTrJ) is no longer statistically significant, but the negative effect of de facto trade globalisation (KOFTrF) is statistically significant. The estimates of de jure and de facto social globalisation are consistent with those in Table 3. The determined significance of the effect of the globalisation on income inequality, using (D10/D1) and (Q5/Q1), is somewhat distinct from those estimated when the net GINI coefficient is used and suggests that results are ambiguous. This may be because the operationalisation of income inequality to some extent made an impact on our research results.

Gini index is more responsive to changes around the mean of the income distribution than decile ratio or quintile ratio and it does not consider if income inequality alters because the poor become poorer, or the rich become richer, or both (Dorn et al., 2017). Each indicator of income inequality focuses on one part of the full distribution and therefore does not provide full information or sheds light on different aspects of inequality. We also cannot eliminate the possibility the panel is not homogeneous according to the income inequality level and development level. We recommend further research in this direction.

As regards the control variables, SocProt negatively influences income inequality, and this impact is statistically significant in all specifications. Observing the impact of Depend on income inequality, using D10/D1 and Q5/Q1 as dependent variables, is the same as using the GIN/ coefficient and is in line with what one might expect. An increase in Depend by $1 \%$ increases inequality by $1.2-1.4 \%$ when inequality is measured by the $D 10 / D 1$, and by $0.64-0.73 \%$ when inequality is measured by the $Q 5 / Q 1$.

\section{CONCLUSIONS}

Income inequality and globalisation in the EU countries have changed dramatically over the last two decades. Economic theory does not provide an unambiguous projection of the influence of various globalisation dimensions on income inequality. Contradictory results have been obtained in empirical studies that assessed the influence of globalisation on income inequality. While some studies confirm the hypothesis that globalisation increases income inequality, others disagree with this conclusion. Scientists reach different and even controversial results due to different measures of globalisation and income inequality, different model specifications, different periods and samples of countries. The present research provides a deeper analysis of this significant topic.

In contrast to preceding research, using the KOF globalisation index database, we control the influence of several globalisation dimensions (trade, financial, political, and social) on income inequality separately. We assess the impact of each dimension, using de facto and de jure indicators. This is done using a one-step system GMM estimation method which accounts for the endogeneity issue. As a test of sensitivity, we use decile ratios and quintile ratios as dependent variables. The research covers 27 EU countries for the period of 1998-2017.

The conducted research confirms four out of seven hypotheses. The main results obtained from a one-step system GMM model reveal that trade and financial globalisation, defined by policies (de jure), has a different influence on inequality than trade globalisation defined by outcomes (de facto). Overall, the results indicate that de jure trade globalisation, measured by tariffs, trade regulations, etc., is the driving force of income inequality. Results demonstrate that liberalisation of restrictions on flows of goods, capital, and labour across borders is more useful for large companies than small enterprises and rising income is not equally shared between various segments of population.

We find evidence that a greater extent of de jure financial globalisation is related to greater inequality. Political globalisation is a complex process and results show that de facto political globalisation contributes to greater income equality, while de jure political globalisation promotes more inequality. The influence of social globalisation on income inequality is statistically insignificant. Trying to correct the influence of other factors that may affect income inequality, we incorporate the same control variables in all the model specifications. 
To test the sensitivity of the results, we use the other measures of inequality: decile ratio and quintile ratio. The results indicate a positive but statistically insignificant relationship between de jure trade globalisation and inequality. But when we use the decile ratio and quintile ratio instead of the Gini index as the dependent variable, our findings show a negative and significant effect of de facto trade globalisation on income inequality. This demonstrates that estimates are sensitive to measures of income inequality. Overall, results are in line with Auguste (2018). Globalisation is a complex and multidimensional process, that is why some of its dimensions contribute to greater income equality, some may have no or negligible effect, while others promote more inequality.

Taking into consideration the results of this research, it seems that policymakers need to rethink their approach to the trade globalisation policy, and first-order discussions and concerns must be the question of who receives benefits and who loses from changes in trade policy. The results of this research represent a supplementary contribution to the discussion by emphasizing the impact of various de jure and de facto indicators of various globalisation dimensions on income inequality.

\section{Limitations and suggestions for future research}

The research leaves several issues that should be considered in future research. First, the EU countries are not homogeneous according to the development level and seeking to get a deeper understanding of the estimates, we may split the countries into relatively higher and relatively less developed EU country groups and evaluate whether the impact of de jure and de facto indicators of different globalisation dimensions is of the same signs and significance in different EU country groups. Moreover, it can be assessed if the impact of various de jure and de facto globalisation measures varies across advanced, emerging economies and developing markets. Second, when evaluating the impact of de jure and de facto indicators of various dimensions of globalisation on income inequality, we used the dynamic panel GMM approach. Other approaches may also be used to investigate this impact. Third, the nexus between various globalisation dimensions and inequality can be non-linear: income inequality may firstly increase and then decrease in the globalisation process. Finally, future research should present trade policy recommendations ensuring that trade policy not only increases efficiency but also reduces income inequality within and between countries.

\section{REFERENCES}

Åberg, R. (1989). Distributive Mechanisms of the Welfare State, a Formal Analysis and an Empirical Application. European Sociological Review, 5(2), 167-182. https://doi.org/10.1093/oxfordjournals.esr.a036514

Agnello, L., Mallick, S.K., \& Sousa, R.M. (2012). Financial Reforms and Income Inequality. Economics Letters, 116(3), 583-587. https://doi.org/10.1016/j.econlet.2012.06.005

Asteriou, D., Dimelis, S., \& Moudatsou, A. (2014). Globalization and Income Inequality: A panel Data Econometric Approach for the EU27 Countries. Economic Modelling, 36, 592-599. https://doi.org/10.1016/j.econmod.2013.09.051

Auguste, D. (2018). Income Inequality, Globalization, and the Welfare State: Evidence from 23 Industrial Countries, 1990-2009. Sociological Forum, 33(3), 666-689. https://doi.org/10.1111/socf.12437

Babones, S.J., \& Vonada, D.C. (2009). Trade Globalization and National Income Inequality - Are They Related?. Journal of Sociology, 45(1), 5-30. https://doi.org/10.1177/1440783308099984

Berg, A.J., Ostry, J.D., \& Zettelmeyer, J. (2012). What Makes Growth Sustained. Journal of Development Economics, 98(2), 149-166. https://doi.org/10.1016/j.jdeveco.2011.08.002

Bergh, A., \& Nilsson, T. (2010). Do Liberalization and Globalization Increase Income Inequality?. European Journal of Political Economy, 26(4), 488-505. https://doi.org/10.1016/j.ejpoleco.2010.03.002

Brady, D., \& Sosnaud, B. (2009). The Politics of Economic Inequality. In K.T. Leicht \& J.C. Jenkins (Eds.), Handbook of politics (pp. 521-541). New York: Springer. https://doi.org/10.1007/978-0-387-68930-2

Cabral, R., García-Díaz, R., \& Mollick, A.V. (2016). Does Globalization Affect Top Income Inequality?. Journal of Policy Modeling, 38(5), 916-940. https://doi.org/10.1016/j.jpolmod.2016.05.001 
Cassette, A., Fleury, N., \& Petit, S. (2012). Income Inequalities and International Trade in Goods and Services: Short- and Long-Run Evidence. The International Trade Journal, 26(3), 223-254. https://doi.org/10.1080/08853908.2012.682023

Dabla-Norris, E., Kochhar, K., Suphaphiphat, N., Ricka, F., \& Tsounta, E. (2015). Causes and Consequences of Income Inequality: A Global Perspective. IMF Staff Discussion Note, 15(13). Washington, DC: International Monetary Fund. Retrieved from https://gsdrc.org/document-library/causes-and-consequences-of-incomeinequality-a-global-perspective/ on September 20, 2020.

De Haan, J., \& Sturm, J.E. (2017). Finance and Income Inequality: A Review and New Evidence. European Journal of Political Economy, 50, 171-195. https://doi.org/10.1016/j.ejpoleco.2017.04.007

Dorn, F., Fuest, C., \& Potrafke, N. (2017). Globalisation and Income Inequality Revisited. Discussion Paper, 056, 1-46. https://doi.org/10.2765/5830

Dreher, A. (2006). The Influence of Globalization on Taxes and Social Policy: An Empirical Analysis for OECD Countries. European Journal of Political Economy, 22(1), 179-201. https://doi.org/10.1016/j.ejpoleco.2005.04.006

Dreher, A., \& Gaston, N. (2008). Has Globalization Increased Inequality?. Review of International Economics, 16(3), 516-536. https://doi.org/10.1111/j.1467-9396.2008.00743.x

Eppinger, P., \& Potrafke, N. (2016). Did Globalisation Influence Credit Market Deregulation?. World Economy, 39(3), 444-473. https://doi.org/10.1111/twec.12282 3

Faustino, H., \& Vali, C. (2013). The Effects of Globalization and Economic Growth on Income Inequality: Evidence for 24 OECD Countries. Argumenta Oeconomica, 1(30), 13-31.

Feenstra, R.C., \& Hanson, G.H. (1997). Foreign Direct Investment and Relative Wages: Evidence from Mexico's Maquiladoras. Journal of International Economics, 42, 371-393. https://doi.org/10.1016/S00221996(96)01475-4

Figini, P., \& Gorg, H. (1999). Multinational Companies and Wage Inequality in the Host Country: The Case of Ireland. Weltwirtschaftliches Archiv, 135(4), 594-612. https://doi.org/10.1007/BF02707386

Gourdon, J., Maystre, N., \& de Melo, J. (2008). Openness, Inequality and Poverty: Endowments Matter. The Journal of International Trade \& Economic Development, 17(3), 343-378. https://doi.org/10.1080/09638190802136978

Gozgor, G., \& Ranjan, P. (2015). Globalisation, Inequality, and Redistribution: Theory and Evidence. CESifo Working Paper, 5522, 1-37. https://doi.org/10.13140/RG.2.1.1410.6320

Gradstein, M. (2007). Inequality, Democracy and the Protection of Property Rights. The Economic Journal, 117, 252-270. https://doi.org/10.1111/j.1468-0297.2007.02010.x

Gygli, S., Haelg, F., Potrafke, N., \& Sturm, J.E. (2019). The KOF Globalisation Index - revisited. The Review of International Organizations, 1-32. https://doi.org/10.1007/s11558-019-09344-2

IMF. (2007). Globalization and Inequality. World Economic Outlook October 2007, 135-170. Retrieved from https:/ /www.imf.org/en/Publications/WEO/Issues/2016/12/31/Globalization-and-Inequality on September 20, 2020.

Jaumotte, F., Lall, S., \& Papageorgiou, C. (2013). Rising Income Inequality: Technology, or Trade and Financial Globalization?. IMF Economic Review, 61(2), 271-309. https://doi.org/10.1057/imfer.2013.7

Jestl, S., Leitner, S.M., \& Leitner, S. (2018). The Relative Impact of Different Forces of Globalisation on Wage Inequality: A Fresh Look at the EU Experience. Working Paper, 154, 1-50.

Ketokivi, M., \& McIntosh, C.N. (2017). Addressing the Endogeneity Dilemma in Operations Management Research: Theoretical, Empirical, and Pragmatic Considerations. Journal of Operations Management, 52, 1-14. https://doi.org/10.1016/j.jom.2017.05.001

Khadraoui, N., \& Smida, M. (2012). Financial Development and Economic Growth: Static and Dynamic Panel Data Analysis. International Journal of Economics and Finance, 4(5), 94-104. https://doi.org/10.5539/ijef.v4n5p94

Kochan, T.A., \& Riordan, C.A. (2016). Employment Relations and Growing Income Inequality: Causes and Potential Options for its Reversal. Journal of Industrial Relations, 58(3), 419-40. https://doi.org/10.1177/0022185616634337

Kose, M.A., Prasad, E., Rogoff, K., \& Wei, S-J. (2009). Financial Globalization: A Reappraisal. International Monetary Fund. Staff Papers, 56(1), 8-62.

Kunieda, T., Okada, K., \& Shibata, A. (2014). Finance and Inequality: How does Globalization Change their Relationship?. Macroeconomic Dynamics, 18(5), 1091-1128. https://doi.org/10.1017/S1365100512000843 
Lee, C.-C., Lee, C.-C., \& Lien, D. (2020). Income Inequality, Globalization, and Country Risk: a CrossCountry Analysis. Technological and Economic Development of Economy, 26(2), 379-404. https://doi.org/10.3846/tede.2019.11414

Martens, P., Caselli, M., De Lombaerde, P., Figge, L., \& Scholte, J.A. (2015). New Directions in Globalization Indices. Globalizations, 12(2), 217-228. https://doi.org/10.1080/14747731.2014.944336

Melitz, M. (2003). The Impact of Trade on Intra-Industry Reallocations and Aggregate Industry Productivity. Econometrica, 71(5), 1695-1725. https://doi.org/10.1111/1468-0262.00467

Pérez-Moreno, S., \& Angulo-Guerrero, M.J. (2016). Does Economic Freedom Increase Income Inequality? Evidence from the EU countries. Journal of Economic Policy Reform, 19(4), 327-347. https://doi.org/10.1080/17487870.2015.1128832

Potrafke, N. (2013). Globalisation and Labor Market Institutions: International Empirical Evidence. Journal of Comparative Economics, 41(3), 829-842. https://doi.org/10.1016/j.jce.2013.02.002

Potrafke, N. (2015). The Evidence on Globalisation. The World Economy, 38(3), 509-552. https://doi.org/10.1111/twec.12174

Roine, J., Vlachos, J., \& Waldenström, D. (2009). The Long-Run Determinants of Inequality: What Can We Learn from Top Income Data?. Journal of Public Economics, 93(7-8), 974-988. https://doi.org/10.1016/j.jpubeco.2009.04.003

Sánchez-López, C., Aceytuno, M.T., \& de Paz-Báñez, M.A. (2019). Inequality and Globalisation: Analysis of European Countries. Economics and Sociology, 12(4), 84-100. https://doi.org/10.14254/2071-789X.2019/12-4/5

Schmid, K.D., \& Stein, U. (2013). Explaining Rising Income Inequality in Germany, 1991-2010. IMK Studies, IMK at the Hans Boeckler Foundation, Macroeconomic Policy Institute, 32. Retrieved from https://www.boeckler.de/pdf/p_imk_study_32_2013.pdf on September 20, 2020.

Shahbaz, M., Shahzad, S.J.H., Mahalik, M.K., \& Hammoudeh, S. (2018). Does Globalisation Worsen Environmental Quality in Developed Economies?. Environmental Modeling \& Assessment, 23(2), 141-156. https://doi.org/10.1007/s10666-017-9574-2

Tridico, P., \& Pariboni, R. (2018). Theoretical and Empirical Analyses of the Rise of Income Inequality in Rich Countries. In P. Arestis \& M. Sawyer (Eds.), Inequality. Trends, Causes, Consequences, Relevant Policies (pp. 139-186). International Papers in Political Economy. Cham: Palgrave Macmillan. https://doi.org/10.1007/978-3-319-91298-1_4

Tsai, M. (2007). Does globalization affect human well-being?. Social Indicators Research, 81, $103-126$. https://doi.org/10.1007/s11205-006-0017-8

Ullah, S., Akhtar, P., \& Zaefarian, G. (2018). Dealing with Endogeneity Bias: The Generalized Method of Moments for Panel Data. Industrial Marketing Management, 71, 61-78. https://doi.org/10.1016/j.indmarman.2017.11.010

Valentin, F., Lang, V.F., \& Tavares, M.M. (2018). The Distribution of Gains from Globalization. IMF Working Papers, 18(054), 1-66. International Monetary Fund. Retrieved from https://www.imf.org/en/Publications/WP/Issues/2018/03/13/The-Distribution-of-Gains-from-Globalization-45722 on September 20, 2020.

Voigt, S., Gutmann, J., \& Feld, L.P. (2015). Economic Growth and Judicial Independence, a Dozen Years On: CrossCountry Evidence Using an Updated Set of Indicators. European Journal of Political Economy, 38, 197-211. https://doi.org/10.1016/j.ejpoleco.2015.01.004

Wintoki, M.B., Linck, J.S., \& Netter, J.M. (2012). Endogeneity and the Dynamics of Internal Corporate Governance. Journal of Financial Economics, 105(3), 581-606. https://doi.org/10.1016/j.jfineco.2012.03.005

Yay, G., Taştan, H., \& Oktayer, A. (2016). Globalization, Economic Freedom, and Wage Inequality: A Panel Data Analysis. Panoeconomicus, 63(5), 581-601. https://doi.org/10.2298/PAN130515024Y

Zhou, L., Biswasy, B., Bowlesz, B., \& Saunders, P. (2011). Impact of Globalization on Income Distribution Inequality in 60 Countries. Global Economy Journal, 11(1), 1-18. https://doi.org/10.2202/1524-5861.1628 


\section{Authors}

The contribution share of the authors is as follows: Z. Tamasauskiene $-60 \%$, S. Žickienè $-40 \%$.

\section{Zita Tamasauskiene}

PhD in Economics (Vilnius University, Lithuania). Professor of the Regional Development Institute, Šiauliai Academy of Vilnius University. Her research interests include income inequality, social policy, human capital. Correspondence to: Prof. Zita Tamasauskiene, PhD, Vilnius University, Šiauliai Academy, Regional Development Institute, P. Višinskio g. 38, Šiauliai, Lithuania, e-mail: zita.tamasauskiene@sa.vu.It

ORCID (1) http://orcid.org/0000-0002-5363-6892

\section{Skaidrè Žickienè}

PhD in Economics (Vilnius Gediminas Technical University). Professor of the Regional Development Institute, Šiauliai Academy of Vilnius University. Her research interests include sustainable development, income distribution, corporate social responsibility.

Correspondence to: Prof. Skaidrè Žickienė, PhD, Vilnius University, Šiauliai Academy, Regional Development Institute, P. Višinskio g. 38, Šiauliai, Lithuania, e-mail: skaidre.zickiene@sa.vu.It

ORCID (1) http://orcid.org/0000-0001-5780-0402

\section{Acknowledgements and Financial Disclosure}

The authors would like to thank the anonymous three referees and the Associate Editor dr Agnieszka Wałęga for their useful comments, tips which allowed to increase the value of this article.

\section{Conflict of Interest}

The authors declare that the research was conducted in the absence of any commercial or financial relationships that could be construed as a potential conflict of interest.

\section{Copyright and License}

This article is published under the terms of the Creative Commons

Attribution - NoDerivs (CC BY-ND 4.0) License

http://creativecommons.org/licenses/by-nd/4.0/

Published by Cracow University of Economics - Krakow, Poland 
